\title{
Corrigendum: Customer experience, satisfaction and loyalty in business-to-business markets: Does the chain hold across customer segments?
}

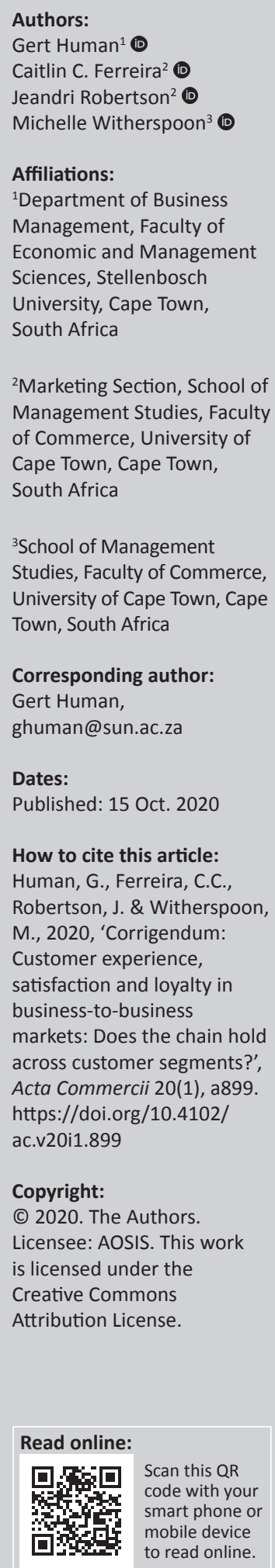

${ }^{2}$ Marketing Section, School of Management Studies, Faculty of Commerce, University of Cape Town, Cape Town, South Africa

\section{${ }^{3}$ School of Management} Studies, Faculty of Commerce, University of Cape Town, Cape Town, South Africa

\section{Corresponding author:} Gert Human,

ghuman@sun.ac.za

Dates:

Published: 15 Oct. 2020

How to cite this article: Human, G., Ferreira, C.C., Robertson, J. \& Witherspoon, M., 2020, 'Corrigendum: Customer experience, satisfaction and loyalty in business-to-business markets: Does the chain hold across customer segments?', Acta Commercii 20(1), a899. https://doi.org/10.4102/ ac.v20i1.899

\section{Copyright:}

(C) 2020. The Authors. Licensee: AOSIS. This work

is licensed under the Creative Commons Attribution License.

In the version of the article initially published, Human, G., Ferreira, C.C., Robertson, J. \& Whiterspoon, M., 2020, 'Customer experience, satisfaction and loyalty in business-to-business markets: Does the chain hold across customer segments?', Acta Commercii 20(1), a855. https://doi.org/10.4102/ac.v20i1.855, the surname of the fourth author was given incorrectly. The correct surname should be Witherspoon instead of Whiterspoon in the 'Author' and 'How to cite this article' sections.

This correction does not alter the study's findings of significance or overall interpretation of the results. The authors apologise for any inconvenience caused. 


\section{Customer experience, satisfaction and loyalty in business-to-business markets: Does the chain hold across customer segments?}

\begin{tabular}{|c|c|}
\hline \multicolumn{2}{|c|}{$\begin{array}{l}\text { Authors: } \\
\text { Gert Human } 1 \\
\text { Caitlin C. Ferreira }^{2} \\
\text { Jeandri Robertson } \\
\text { Michelle Whiterspoon }\end{array}$} \\
\hline $\begin{array}{l}\text { Affiliations: } \\
{ }^{1} \text { Department } \\
\text { Management, } \\
\text { Economic and } \\
\text { Sciences, Stell } \\
\text { University, Ca } \\
\text { South Africa }\end{array}$ & $\begin{array}{l}\text { ff Business } \\
\text { Faculty of } \\
\text { Management } \\
\text { enbosch } \\
\text { pe Town, }\end{array}$ \\
\hline $\begin{array}{l}{ }^{2} \text { Marketing Se } \\
\text { Management } \\
\text { of Commerce, } \\
\text { Cape Town, C } \\
\text { South Africa }\end{array}$ & $\begin{array}{l}\text { ction, School of } \\
\text { Studies, Faculty } \\
\text { University of } \\
\text { pe Town, }\end{array}$ \\
\hline $\begin{array}{l}{ }^{3} \text { School of Ma } \\
\text { Studies, Facult } \\
\text { University of C } \\
\text { Cape Town, Sc }\end{array}$ & $\begin{array}{l}\text { lagement } \\
\text { y of Commerce, } \\
\text { ape Town, } \\
\text { uth Africa }\end{array}$ \\
\hline $\begin{array}{l}\text { Correspondin } \\
\text { Gert Human, } \\
\text { ghuman@sun }\end{array}$ & $\begin{array}{l}\text { g author: } \\
\text { ac.za }\end{array}$ \\
\hline $\begin{array}{l}\text { Dates: } \\
\text { Received: } 04 \text { F } \\
\text { Accepted: } 14 \\
\text { Published: } 21\end{array}$ & $\begin{array}{l}\text { eb. } 2020 \\
\text { May } 2020 \\
\text { July } 2020\end{array}$ \\
\hline $\begin{array}{l}\text { How to cite th } \\
\text { Human, G., Fe } \\
\text { Robertson, J. } \\
\text { Whiterspoon, } \\
\text { 'Customer exp } \\
\text { satisfaction ar } \\
\text { business-to-b } \\
\text { markets: Does } \\
\text { across custom } \\
\text { Acta Commer } \\
\text { https://doi.or } \\
\text { ac.v20i1.855 }\end{array}$ & $\begin{array}{l}\text { is article: } \\
\text { rreira, C.C., } \\
\text { \& } \\
\text { M., 2020, } \\
\text { erience, } \\
\text { d loyalty in } \\
\text { usiness } \\
\text { the chain hold } \\
\text { er segments?', } \\
\text { cii } 20(1) \text {, a855. } \\
\text { 3/10.4102/ }\end{array}$ \\
\hline $\begin{array}{l}\text { Copyright: } \\
\text { (c) 2020. The } A \\
\text { Licensee: AOS } \\
\text { is licensed un } \\
\text { Creative Comr } \\
\text { Attribution Lic }\end{array}$ & $\begin{array}{l}\text { uthors. } \\
\text { IS. This work } \\
\text { der the } \\
\text { nons } \\
\text { ense. }\end{array}$ \\
\hline 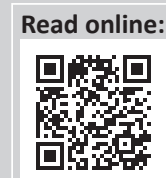 & $\begin{array}{l}\text { Scan this QR } \\
\text { code with your } \\
\text { smart phone or } \\
\text { mobile device } \\
\text { to read online. }\end{array}$ \\
\hline
\end{tabular}

Orientation: This study considers the influence of customer experience gained during sales interaction episodes on customer satisfaction, customer loyalty and ultimately willingness to recommend the focal firm in a business-to-business context and compares these associations across multiple firm-specific customer segments.

Research purpose: This study seeks to examine whether an experience-satisfaction-loyalty causal model would hold across case-specific heterogeneous customer segments in a businessto-business context.

Motivation for the study: Industrial marketing researchers often overlook customer experiences, particularly relating to sales interactions. These interactions are prone to variation across customer segments, and the associated heterogeneity may lead to gaps in our understanding of how such interactions could impact customer loyalty and ultimately willingness to recommend a firm in a business-to-business context.

Research design, approach and method: The quantitative design made use of a focal firm approach as a single case study of enquiry, surveying a valid sample of 1004 of the focal firm's customers. The data was analysed using variance based structural equation modelling after being subjected to validity and reliability testing. The multigroup analysis was conducted using case driven characteristics to compare the theoretical model across customer segments.

Main findings: A simplified model to explain willingness to recommend was subjected to multi-group analyses across four key theoretical relationship dimensions. The results provide support for linkages between sales interaction experience, customer satisfaction, loyalty and ultimately willingness to recommend.

Practical/managerial implications: The findings could facilitate the development of relationship management strategies that account for the heterogeneity in customer segments.

Contribution/value-add: It appears useful to consider the heterogeneity that may exist between customer groups and segments that could potentially distort assumed linear associations.

Keywords: relationship marketing; emerging market; interaction experience; customer satisfaction; market heterogeneity.

\section{Introduction}

Every interaction with your company is another opportunity for your customer to determine if you are exceptional or not.

- Lisa Masiello

The notion that the quality of a purchase experience influences customer satisfaction, which in turn could impact customer loyalty to a particular seller, is common ground in marketing literature (De Haan, Verhoef \& Wiesel 2015; Olsen 2002). Business-to-business markets and the relationships that buyers and sellers construct in those markets, however, entail complex and multi-level dimensions (Lemon \& Verhoef 2016; Leonidou \& Hultman 2019; Roberts-Lombard, Mpinganjira \& Svensson 2019). These complex relationships and concomitant customer experiences represent heterogeneity that may challenge the underlying assumptions that drive the relationship development strategies of firms (Grönroos 2017; Paparoidamis, Katsikeas \& Chumpitaz 2019). 
Recent advances in customer experience research, in particular, underscore its invaluable importance as a key driver of success for companies across various industries (Grønholdt et al. 2015; Klaus \& Maklan 2013; Lemke, Clark \& Wilson 2011; Palmer 2010; Verhoef et al. 2009; Witell et al. 2019; Zolkiewski et al. 2017). Hollyoake (2009) operationally delineates that customer experiences within business-tobusiness settings are not differentiated by the relationship or the way customers are managed, but more so by the experience that is developed through the relationship. In turn, Palmer (2010) accentuates the link between customer experience, customer satisfaction and long-term loyalty, with most research mainly focusing on business-to-customer rather than business-to-business contexts. For the purposes of this study, we refer to this chain as the quality-satisfactionloyalty-performance causal chain (or paradigm) to aid the economy of our discussion.

The business-to-business marketing literature is increasingly highlighting the importance of multiple perspectives on improving firm performance through enhancing the customer experience - and hence the loyalty of and relationships with customers (Ata \& Toker 2012; Hlefana, Roberts-Lombard \& Stiehler-Mulder 2020; Magno \& Cassia 2019). Within this apparent loyalty-performance paradigm, the empirical investigation of the customer's experience, particularly during sales interactions, is often overlooked by industrial marketing researchers (Biggemann \& Buttle 2009; Evans et al. 2012; Kaski, Niemi \& Pullins 2018). This is especially true in contextually sensitive (Nguyen, Barrett \& Miller 2011) and customer diverse (Sheth \& Sinha 2015) emerging market environments, where there is limited research and knowledge of the customer experience and concomitant long-term loyalty of heterogeneous customer segments in a business-to-business setting (Biggemann \& Fam 2011; Gupta, Balmer \& Low 2015; Witell et al. 2019). Customer-centric approaches that move beyond the single sales transaction have shown to pave the way for marketers to maximise and pursue customer satisfaction, customer retention and ultimately loyalty (Walter 1999). In addition, customer relationship management researchers have demonstrated that customer recommendations act as a powerful weapon in the competitive arsenal of modern marketers, including emerging markets (Issock, Mpinganjira \& Roberts-Lombard 2019; Olaru, Purchase \& Peterson 2008; Schreier, Fuchs \& Dahl 2012; Van Tonder \& Roberts-Lombard 2016).

Business customers' experiences with a firm shape the nature of the relationship, which could either surpass expectations and satisfy customers or fail to meet expectations resulting in dissatisfied customers (Zolkiewski et al. 2017). Ultimately, this satisfaction, or lack thereof, influences customer loyalty and subsequent actions associated with a loyal customer, such as their willingness to recommend (WTR) the firm to others (Hallowell 1996; Kwiatek, Morgan \& Thanasi-Boçe 2020). Examining this typical causal chain to explain loyalty brings into question whether we can maintain the current notion to generalise the strength and directionality across heterogeneous business customer segments. Thus, understanding whether such a typical causal model would hold across heterogeneous customer segments provides greater insight into the varying importance of the drivers of loyalty. Ramaseshan, Rabbanee and Hui (2013) suggest that the drivers of loyalty in business markets differ greatly, depending on the nature of the targeted customer. In light of this, the primary objective of this study is to investigate if a causal chain to explain WTR holds true across different customer segments, empirically generated as a result of the strategies of a focal firm. The WTR the firm was selected as a proxy measure for loyalty because of the commonly cited understanding that loyal customers are far more likely to engage in recommendations (Ferguson, Paulin \& Bergeron 2009; Keiningham et al. 2007a). Given that customer loyalty presents as a multidimensional construct, WTR has often been cited as a proxy measure for sub-dimensions of customer loyalty (Bloemer, De Ruyter \& Wetzels 1999; Prayag 2011).

As such, the contribution of this article resides primarily in the notion that although business-to-business marketing has benefitted from the scientific isolation of near-linear causal effects, it is useful to consider the heterogeneity that may exist between groups that could potentially distort assumed linear associations. This should facilitate the development of relationship management strategies and policies that are less inclined to assume a 'one size fits all' approach, when considering interactions with a wide range of business customers, with the firm goal still being enhanced financial performance.

In order to achieve this objective, a latent sales interaction experience construct (called Sales Interaction Experience [SIE]) has been used to understand how the customer's experience during a sales interaction drives both customer satisfaction and WTR, thus maintaining the commonly used satisfaction to recommendation linkage (Aksoy et al. 2011; Keiningham et al. 2007a). In order to provide further insight into the role of these linkages between heterogeneous customer segments, four key theoretical grouping variables have been identified based on the strategies and initiatives of the focal firm. These are groups that are indicative of different market segments, the results of strategy choice by the firm, contractual commitments and the specific types of interaction. In addition, the case-based identification of customer segments was matched to literature using similar groupings in order to further justify their selection.

The rationale for this multi-segment analysis lies in the market heterogeneity that is often experienced in businessto-business markets (Li, Fong \& Xu 2011; Pilehvar, Elmaghraby \& Gopal 2017). An analysis of these group comparisons seeks to provide further insight into possible differences in the causal linkages between SIE, satisfaction and WTR.

The section to follow provides a synopsis of relevant literature, followed by a methodology that outlines the data collection and analytical procedures employed in the study. 
The article then reports the results before drawing conclusions and offering questions for future research.

\section{Theoretical background Customer experience}

A positive customer experience during the purchasing process contributes to customer satisfaction with the purchase, can enhance customer loyalty to the seller and is a powerful tool in retaining and attracting new customers (De Haan et al. 2015; Olsen 2002). Storbacka, Strandvik and Grönroos (1994) posit that a satisfied customer would create a strong relationship with the seller, which would lead to relationship longevity through customer retention and customer loyalty. Furthermore, Uncles, East and Lomax (2010) have suggested that positive customer experiences are correlated with enhanced customer loyalty and ultimately improve firm performance. Kumar et al. (2013) define customer loyalty as customers who exhibit both behavioural and attitudinal loyalty to a specific trading partner.

As indicated in the 'Introduction' section, we postulate that these constructs could sequentially act as drivers which ultimately translate into a WTR the firm to other customers and/or buyers. Although beyond the scope of this particular study, other constructs that also influence WTR have been mentioned in the literature. For example, Olaru et al. (2008) demonstrated the importance of perceived value and its impact on repurchase intentions and WTR. Yet other researchers have suggested that WTR may not be an end in itself. Rather it may, especially in a service setting, influence future willingness to purchase and engage with the counterpart (see, e.g., Aksoy et al. 2011). It is important to note that the key objective is not to create a parsimonious model to explain WTR, but rather to demonstrate the presence and influence of heterogeneity associated with different customer segments. This study seeks to demonstrate the limitations of causal inference across groups. As per Zablah, Bellenger and Johnston (2004:475), customer relationship management is an iterative process which involves the on-going development and leveraging of market intelligence 'for the purpose of building and maintaining a profit-maximizing portfolio of customer relationships'. With this in mind, the key constructs of this study are operationalised in the following sections to aid development of our conceptual framework.

\section{Willingness to recommend}

The idea of WTR is common in the customer satisfactionloyalty literature and is often associated with the work of Reichheld (2003) and the well-known Net Promoter Score (NPS) management tool. Willingness to recommend has received significant attention since Reichheld (2003) established the NPS with a stream of research rekindling the original word-of-mouth research of Dichter published in 1966 (Kietzmann \& Canhoto 2013). Primarily, the NPS of a firm is considered a metric to gauge customer satisfaction. When customers are happy with a product or a service, they may be more inclined to recommend the product or service to others. In business-to-business marketing literature, the notion of WTR is widely used in healthcare and tourism industries. The concept gained notable traction in developing technology acceptance models (see, e.g. Venkatesh \& Bala 2008; Venkatesh, Davis \& Morris 2007) and today it frequents business-to-business studies. For example, Kwiatek et al. (2020) noted that the willingness to recommend a supplier results from a positive evaluation of that supplier, thus indicating preference for the supplier. Moreover, these authors (Kwiatek et al. 2020) demonstrated that relationship quality drives the willingness of business-to-business customers to recommend loyalty programmes. Therefore, our use of WTR is consistent with prevailing business-tobusiness literature (Buttle 1996; Kwiatek et al. 2020; Stocchi, Michaelidou \& Micevski 2019).

Customers commonly use word-of-mouth referrals as important sources of information to assist the evaluation of complex business services (Olaru et al. 2008). Research has provided numerous examples of instances in which customers may be inclined to recommend the products or services of another firm. When customers are willing to recommend a product or service to relatives or friends, they do more than indicate that they have received good economic value from a firm; they also put their own reputations at stake (Eisingerich \& Bell 2007). Denning (2011) showed that in many of the industries the percentage of customers who were enthusiastic enough to refer a friend or colleague, correlated directly with whether they actually recommended the firm. The relationship between WTR and actual behaviour also appears to be strong. For example, Keiningham et al. (2007b) reported that the likelihood to recommend a firm correlate highly with actual customer behaviour. More explicitly, if customers reported that they were likely to recommend a particular firm to a friend or colleague, these customers were also likely to repurchase from the firm and generate new business through word-of-mouth.

This association between intention and behaviour remains a key reason driving proponents of NPS to recommend it as the most important loyalty measure. The NPS has received much scholarly attention (De Haan et al. 2015; Keiningham et al. 2007b; Kristensen \& Eskildsen 2014) and its usefulness is rigorously debated in the business-to-business literature and beyond. Walter (1999) suggests that relationship promoters are often the driving force behind successful customer relationships. Customer satisfaction has been suggested as the primary feeder for positive customer responses about the firm, enhancing one's WTR the firm.

\section{Customer satisfaction}

Austen, Herbst and Bertels (2012) established the importance of customer satisfaction in business-to-business marketing by examining the role of satisfaction in repurchase decisions, whereas whilst Čater and Čater (2009) referred to it as a key construct in maintaining business-to-business relationships. Ryding (2010) adopted the earlier approach by Rust and 
Oliver (1994), arguing that customer satisfaction is a summary of cognitive and affective reactions to service as a result of experiencing a service quality encounter and comparing that encounter with what was expected. In this instance, experiences that are evaluated as exceeding initial expectations result in satisfaction, whereas experiences that are evaluated as falling short of initial expectations result in dissatisfaction. Their approach, emanating from the services marketing literature, is aligned with the focus of our study, which concerns the customer experience resulting from multiple sales interaction episodes or experiences.

Customer satisfaction brings about many benefits for organisations, with researchers arguing that satisfied customers are less price sensitive, tend to purchase additional products and are less influenced by competitors (see, e.g., Fornell et al. 1996). Furthermore, customer satisfaction has been shown to be a significant driver of repeat purchases, cross-selling opportunities, positive word of mouth, price elasticity and customer loyalty in business-to-business markets specifically (Askariazad \& Babakhani 2015; Dick \& Basu 1994; Fornell et al. 1996; Naumann, Williams \& Khan 2009). To assess whether the same will hold in heterogeneous customer segments, the following hypothesis is proposed:

$\mathbf{H}_{1}$ : Customer satisfaction (SAT) is positively associated with WTR.

The various points of interaction between buyers and sellers serve as a precursor to developing and maintaining satisfied customers. As previously noted, one's experiences with a firm, particularly in the business-to-business context, shape the nature of the relationship. Experiences could either surpass expectations and satisfy customers or fail to meet expectations resulting in dissatisfied customers.

\section{Sales interaction experience}

The view of many researchers is that customer experience is generated through a process of buyer-seller interactions across multiple channels (Klaus \& Maklan 2013). This view acknowledges that these interactions are essential for relationship building and enhancing value creation (Salomonson, Åberg \& Allwood 2012). This 'interactionist perspective' (Biggemann \& Buttle 2009:549) is, therefore, associated with the customer experience: it views interaction as a continuous process of 'action-evaluation-reaction' in which the action of one party may initiate further reaction from another. The importance of customer experience in business-to-business relationships has received increasing support in the literature (see, e.g. Hollyoake 2009). It is, therefore, suggested that it is not necessarily the relationship itself, or the way in which customers are managed that establishes differences in customer relationships, most notably in levels of customer satisfaction. But rather, it would appear that it is the interaction experiences that develop as a result of the relationship that is able to influence customer satisfaction. Srivastava and Kaul (2014) established that customer interactions were able to influence customer satisfaction in a business-to-customer context, and the current research seeks to extend this to the business-to-business context in light of the critical nature of interactions for relationship building. Román and Martín (2014) further established that customer satisfaction may be determined by the quality of the sales interaction, whereby a more positive experience would result in enhanced customer satisfaction.

Following this line of argumentation, it is proposed that SIEs would influence customer satisfaction. In particular, a series of positive experiences would result in satisfied customers, whereas a series of negative experiences would result in dissatisfied customers. Hosany and Witham (2009) further suggest that the number of opportunities that an individual has to gain interaction experience bears a substantial influence on one's evaluation of their experience and thus satisfaction or dissatisfaction. The following hypothesis is proposed to test this relationship:

$\mathbf{H}_{2}$ : Sales interaction experience is positively associated with customer satisfaction (SAT).

Palmer (2010) posits that customer experience, whether positive or negative, results from the interaction with a number of different elements created by the service provider. Further elaborating on these different elements, Verhoef et al. (2009) argue that customer experience captures cognitive evaluations, affective responses, as well as a number of social and physical components. Lemke et al. (2011) further demonstrate that customer experience quality is judged with respect to its contribution made to the valuein-use, and that in assessing experience quality in businessto-business contexts, customers place a greater emphasis on firm practices that focus on understanding and delivering value-in-use.

Ferguson et al. (2009) established that all dimensions of a service experience were associated with customers exhibiting positive word-of-mouth intentions. Hosany and Witham (2009) further examined this relationship by examining the experiences of customers in a business-tocustomer context. Their research indicated that not only were satisfied customers more likely to engage in recommendation, but further, that satisfaction acted as a mediator in the relationship between one's experience and their WTR. In light of this, the following hypothesis is proposed to examine this relationship in a business-tobusiness context:

$\mathbf{H}_{3}$ : Sales interaction experience is positively associated with WTR.

The main objective of the current research is to establish whether the above-proposed hypotheses $\left(\mathrm{H}_{1}-\mathrm{H}_{3}\right)$ would hold when tested across a multitude of different customer segments. The rationale for this multi-segment analysis lies in the market heterogeneity that is commonly experienced in business-to-business markets (Pilehvar et al. 2017; Li et al. 2011). As one cannot assume that business customers, differing in terms of a number of market factors, would respond similarly and would exhibit similar levels of loyalty, a multi-segment analysis seeks to evaluate these differences. 


\section{Comparing multiple customer segments of the focal firm}

Using the focal firm approach, customer segments can be constructed on a number of theoretical perspectives; in the current research, these groups were constructed based on the specific operations of the focal firm. Appendix 1 reports the construction of the various groups along four different theoretical perspectives. These include market factors, the nature of interaction between buyers and sellers, billing strategies, contractual commitments and loyalty programme initiatives. In operational terms, these are factors that are able to influence the loyalty exhibited by customers within the focal firm.

\section{Customer segments}

Market factors such as differences between customer segments (Frösén et al. 2016) have shown to influence interaction experiences and loyalty levels. In the current study, the business-to-business context allowed for a distinction to be made between the predominant industries that customers operate in, namely mining industry customers and construction industry customers. These customers make up approximately $95 \%$ of the focal firm's customers. These two particular industries were selected as similar purchases are made for certain application categories. However, it is important to understand that one cannot assume that the needs or preferences of business-to-business customers are homogenous. Traditional segmentation theory used by marketers globally attempts to separate markets based on relevant characteristics with the goal of creating a series of segments each with some common characteristics (Kotler \& Armstrong 2014). It is likely that customers operating in different industries may be seeking varying interactions and deriving satisfaction from different interactions with the focal firm. In order to assess this supposition, the following hypothesis is proposed:

$\mathbf{H}_{4}$ : There are significant differences between the path estimates $($ SAT $\rightarrow$ WTR; SIE $\rightarrow$ SAT; SIE $\rightarrow$ WTR) for mining and construction customers.

\section{Cultural contexts}

International marketing literature suggests that customer loyalty experiences can vary across cultural contexts (Lemon \& Verhoef 2016; Murphy \& Li 2012; Rosenbloom \& Larsen 2003; Ryu, Aydin \& Noh 2008; Witell et al. 2019). The focal firm operates across multiple countries, and therefore, customer experiences and its subsequent impact on customer loyalty are likely to vary across markets. In the current research, the focal firm's operations are predominantly located in the South African market. As such, it is imperative to analyse the experiences and subsequent satisfaction of South African firms and non-South African firms. This could provide further insight into the expectations surrounding interaction experiences and subsequent loyalty for local customers versus international customers. In order to test this supposition, the following hypothesis is proposed:
$\mathbf{H}_{5}$ : There are significant differences between the path estimates for South African and non-South African customers.

\section{Payment terms}

Literature demonstrates that the nature of the interaction between buyer and sellers could influence customer behaviour (Biggemann \& Buttle 2009; Kim \& Choi 2016; Srivastava \& Kaul 2014) For example, the advantages and disadvantages of different payment terms, such as cash payments and providing customer credit, are well documented in management literature (Lee \& Rhee 2011; Robb \& Silver 2006). Whilst cash payments may hold specific benefits for the cash flow and ultimate financial performance of the firm, providing customer credit can reap substantial relational benefits. In order to assess whether the relationships between interaction experience, satisfaction and WTR hold across different customer segments that make use of different payment terms, the following is hypothesised:

$\mathbf{H}_{6}$ : There are significant differences between the path estimates (SAT $\rightarrow$ WTR; SIE $\rightarrow$ SAT; SIE $\rightarrow$ WTR) for cash customers and credit customers.

\section{Billing strategies}

In a similar fashion to payment terms, firms employ different billing strategies to ensure that their accounts receivable is managed optimally and that a sound cash flow is maintained (Pfohl \& Gomm 2009; Boulaksil \& Van Wijk 2018). These billing strategies represent a further interaction variation and as such, it would appear useful to establish whether differences exist between sales order and collection customers (Long Chen 2012; Humphreys, Williams \& Goebel 2008). Both types of billing strategies create the opportunity to provide multiple interaction experiences, ultimately influencing satisfaction and WTR. In order to assess whether this would result in significant differences between these groups, the following hypothesis is proposed:

$\mathbf{H}_{7}$ : There are significant differences between the path estimates (SAT $\rightarrow$ WTR; SIE $\rightarrow$ SAT; SIE $\rightarrow$ WTR) for customers who collect their purchases from the focal firm, and customers who use sales orders.

\section{Contractual commitments}

The literature on contractual commitments in business-tobusiness relationships (Seshadri 2013) indicates that customers are often tied to formal contractual arrangements, and this influences their loyalty behaviour. In addition, and consistent with Williams and Naumann (2011) and Yurynets and Tomiuk (2014), it is reasonable to expect that for customers with parent firm contracts management, the focal firm ensures that these relationships are well managed to guarantee their lifelong value. The focal firm in the current research maintains such parent firm contracts as well as equipment management contracts. When a customer is a subsidiary of a larger firm, the focal firm usually establishes a management contract with the parent firm in order to ensure the oversight and management of the contract from a 
higher level of authority. For the purpose of this research, these contracts will be referred to as MCC (see Appendix 1) contracts. Equipment management contracts form part of the equipment management project established by the focal firm, whereby the firm is contracted to maintain and manage equipment on behalf of customers. In order to assess whether any potential differences exist amongst these customer segments, the following hypothesis is proposed:

$\mathbf{H}_{8}$ : There are significant differences between the path estimates $(\mathrm{SAT} \rightarrow \mathrm{WTR}$; SIE $\rightarrow \mathrm{SAT}$; SIE $\rightarrow$ WTR) for MCC customers and non-MCC customers

$\mathbf{H}_{9}$ : There are significant differences between the path estimates (SAT $\rightarrow$ WTR; SIE $\rightarrow$ SAT; SIE $\rightarrow$ WTR) for equipment management project customers and non-equipment management project customers.

\section{Key account management and loyalty promotion initiatives}

Finally, strategic choices, particularly those pertaining to key account management (KAM) and loyalty promotion initiatives, may impact customers' repurchasing and recommendation behaviours (De Haan et al. 2015; Olaru et al. 2008). A key strategy to enhance loyalty of the focal firm is to implement various customer loyalty programmes.

The first of these is based on the well-known NPS, made famous by the work of Harvard scholar Fred Reichheld in 2003 (Reichheld 2003). For the purposes of the current study, the experiences of promoters are noted as being different from detractors. In order to test whether the satisfaction and ultimate WTR differs between promoters and detractors, the following hypothesis is proposed:

$\mathrm{H}_{10}$ : There are significant differences between the path estimates $(\mathrm{SAT} \rightarrow \mathrm{WTR}$; SIE $\rightarrow$ SAT; SIE $\rightarrow$ WTR) for promoters and detractors.

A second loyalty strategy (called NEW100 for the purpose of this study) involves an attempt by the focal firm to differentiate between the best performing customers, based on purchasing volumes and the rest of the customer base. The objective of the loyalty programme is to identify and recruit key accounts to the loyalty programme.

As a result of this interaction, it is likely that those recruited to the programme would exhibit heightened intentions to remain with the focal firm. Our approach is consistent with the findings of Kwiatek et al. (2020) who demonstrated that the effect of relationship quality on sales and customer share of wallet is strengthened by customer participation in a loyalty programme. Moreover, it was shown that relationship quality directly results in a longer tenure and WTR only for members of a loyalty programme (Kwiatek et al. 2020). By virtue of being selected as one of the best performing customers, it is suggested that this could bear an influence on the interaction experiences that one would have with the focal firm (Lacey \& Morgan 2009; Ramaseshan et al. 2013). In order to assess whether these group differences may influence the subsequent satisfaction and WTR, the following hypothesis is proposed:
$\mathbf{H}_{11}$ : There are significant differences between the path estimates $($ SAT $\rightarrow$ WTR; SIE $\rightarrow$ SAT; SIE $\rightarrow$ WTR) for NEW100 customers and non-NEW100 customers.

The third and final strategy that the focal firm employs to promote customer loyalty is through a KAM (Gounaris \& Tzempelikos 2014) arrangement with certain clients. Under this programme, customers are assigned to specific salespeople for account management treatment based on the size of purchasing and/or their strategic importance to the focal firm. The efficacy of the KAM initiative is such that those who receive KAM treatment will likely have different interaction experiences to those who do not receive such treatment (Abratt \& Kelly 2002; Pardo et al. 2006). In order to test this supposition, the following hypothesis is proposed:

$\mathbf{H}_{12}$ : There are significant differences between the path estimates $(\mathrm{SAT} \rightarrow \mathrm{WTR}$; SIE $\rightarrow$ SAT; SIE $\rightarrow$ WTR) for KAM customers and non-KAM customers.

As indicated in the preceding section, although these group distinctions enjoy support in the literature, they are derived from the particular context and characteristics of the focal firm and are also specific to a particular market context. In the 'Methodology' section, the collection of the data and the analytical procedures to investigate between-group differences are offered.

The relationships suggested by the aforementioned hypotheses are depicted in Figure 1 and provide an overview of how the various constructs are operationalised in the conceptual model. As seen in Figure 1, the study's conceptual model proposes that customer satisfaction positively influences WTR $\left(\mathrm{H}_{1}\right)$ and that the SIE can act as a driver to influence customer satisfaction $\left(\mathrm{H}_{3}\right)$, as well as directly, positively affecting WTR the firm $\left(\mathrm{H}_{3}\right)$. These hypotheses are proposed to be different for different groups based on the market characteristics $\left(\mathrm{H}_{4}\right.$ and $\left.\mathrm{H}_{5}\right)$, interaction characteristics $\left(\mathrm{H}_{6}\right.$ and $\left.\mathrm{H}_{7}\right)$, contractual commitments $\left(\mathrm{H}_{8}\right.$ and $\left.\mathrm{H}_{9}\right)$ and the firm's strategy $\left(\mathrm{H}_{10}, \mathrm{H}_{11}\right.$ and $\left.\mathrm{H}_{12}\right)$.

\section{Methodology}

Whilst maintaining a positivist orientation, the semiexplorative nature of this study promotes the use of a focal

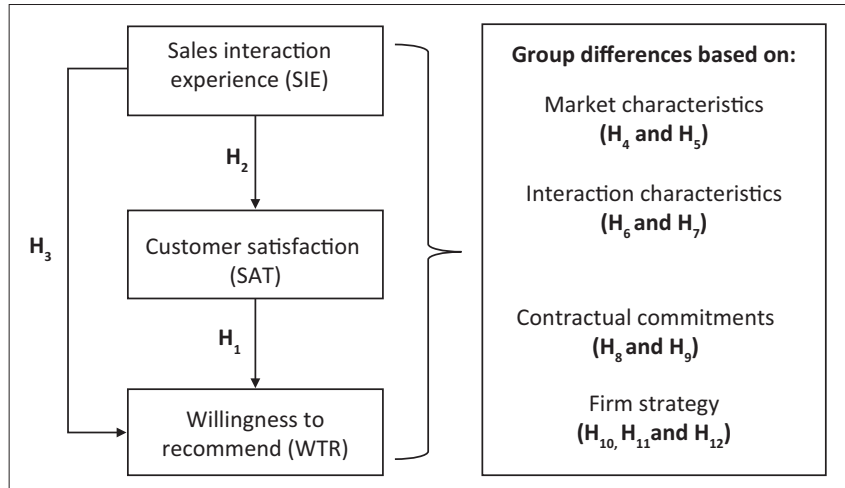

FIGURE 1: Operationalisation of constructs in the conceptual model. 
firm in the context as a case analysis. The motivation for this position is based on the notion that if group differences can be observed in a simplified model of customer experience as driver of customer loyalty intentions, it serves as a point of reference for considering further parsimonious and complex models. The focal firm chosen for this purpose is the official dealer for a global brand of construction, mining and industrial machinery range in 11 southern African countries, as well as Spain, Portugal, Siberia and the Russian Far East. Their African customer base includes South Africa, Lesotho, Swaziland, Namibia, Botswana, Angola, Malawi, Mozambique, Zambia and the Democratic Republic of Congo's Katanga Province. For the purposes of this study, only customers from Africa were considered, and only interactions pertaining to the purchasing of parts were included in an electronic survey. Africa and, in particular, South Africa constitute by far the largest market and investments for the focal firm as $75 \%$ of revenue, $61 \%$ of operating profits, $69 \%$ of operating assets and $80 \%$ of employees stem from this geographical area.

The survey consisted of sections adapted from Lemke et al. (2011) as well as Klaus and Maklan (2013). The first of these measured the interaction experience (three items) of the customers during their interaction with sales staff of the focal firm, whereas the second focused on overall customer satisfaction (three items). A third section focused on the intention to recommend the focal firm (3 items) adopted from Bowen and Chen (2001) and Gil-Saura et al. (2009).

Each item was measured using a 10-point Likert-type scale, where $1=$ very poor and $10=$ excellent. The survey was open for a 3-month period using the full customer base of the focal firm as the sampling frame. A total of 1356 different customers responded to the survey. Closer inspection of the completed surveys revealed a valid sample size of 1004 was suitable for further analysis. Given the number of parameters to estimate in relation to the number of observations, the empirical objective was to make use of an analytical approach that was less sensitive to sample size (Hair et al. 2014). It was, therefore, decided to use a partial least squares path analysis (Hair et al. 2012; Ringle, Wende \& Becker 2015) method, a variancebased structural equation modelling technique. The SmartPLS software was selected as the most appropriate software for the analysis. The psychometric properties of the measurement model were first analysed and tested for common method bias, following this the structural model was evaluated. The multi-group analysis (Schloderer, Sarstedt \& Ringle 2014; Völckner et al. 2010) was then conducted by employing the procedure of Henseler, Ringle and Sinkovics (2009) to evaluate differences between various customer segments.

\section{Ethical consideration}

Ethical clearance was obtained from the Ethics in Research Committee of the Faculty of Commerce at the University of Cape Town. At the time of this study, the University of Cape Town did not issue approval numbers.

\section{Results}

Confirming convergent validity, in the measurement model all indicator items loaded as expected with all loadings exceeding 0.7 (Anderson \& Gerbing 1988). These factor loadings are presented together with reliability and validity measures in Table 1 . The $t$-values generated by the bootstrapping procedure in SmartPLS all exceeded 1.96, demonstrating the statistical significance of all loadings at a 95\% confidence level. Furthermore, the composite reliability and Cronbach's alpha scores all exceed the 0.7 benchmark (Malhotra 2010). This indicates that the scales exhibit satisfactory internal consistency reliability. Average variance extracted (AVE) exceeds 0.5 for all measures indicating acceptable convergent validity (Hair et al. 2014).

Table 2 confirms that the Fornell and Larcker (1981) criterion for discriminant validity has been met. Discriminant validity is further supported by the AVE scores all exceeding the 0.5 threshold value (Malhotra 2010). The AVE statistics are as follows: $\mathrm{WTR}=0.83, \mathrm{SAT}=0.77$ and $\mathrm{SIE}=0.85$.

As the data are pertinent to the field of mining and construction equipment, the test for common method bias using a procedure recommended by Lindell and Whitney (2001) was used. Much like many procedures for common method bias, this procedure has attracted some criticism regarding its conceptualisation (Podsakoff et al. 2003) and its effectiveness (Lance et al. 2010). Nevertheless, it remains widely used, particularly in marketing literature. A marker variable, which is theoretically unrelated to at least one other scale in the measurement instrument, was selected. The correlations amongst constructs were adjusted, and the statistical significance of the adjusted correlations was

TABLE 1: Factor loadings and reliability measures.

\begin{tabular}{lccc}
\hline Item & $\begin{array}{c}\text { Willingness to } \\
\text { recommend (WTR) }\end{array}$ & $\begin{array}{c}\text { Customer } \\
\text { satisfaction (SAT) }\end{array}$ & $\begin{array}{c}\text { Sales interaction } \\
\text { experience (SIE) }\end{array}$ \\
\hline WTR1 & 0.91 & - & - \\
WTR2 & 0.92 & - & - \\
WTR3 & 0.91 & - & - \\
SAT1 & - & 0.86 & - \\
SAT2 & - & 0.90 & - \\
SAT3 & - & 0.86 & - \\
SIE1 & - & - & 0.91 \\
SIE2 & - & - & 0.93 \\
SIE3 & - & - & 0.92 \\
Composite reliability & 0.94 & 0.91 & 0.85 \\
Cronbach's alpha & 0.90 & 0.85 & 0.91 \\
$\begin{array}{l}\text { Average variance } \\
\text { extracted }\end{array}$ & 0.83 & 0.76 & 0.85 \\
\hline
\end{tabular}

TABLE 2: Latent variable correlations, descriptive statistics and discriminant validity criteria.

\begin{tabular}{lccccc}
\hline Construct & Mean & SD & WTR & SAT & SIE \\
\hline Willingness to recommend (WTR) & 8.63 & 1.70 & 0.91 & - & - \\
Customer satisfaction (SAT) & 8.41 & 1.68 & 0.72 & 0.87 & - \\
Sales interaction experience (SIE) & 8.65 & 1.76 & 0.76 & 0.85 & 0.92 \\
\hline SD, standard deviation. & & & & &
\end{tabular}

Note: Square root of AVE on diagonal. 
determined using the formulae proposed by Lindell and Whitney (2001). This analysis allowed for the construction of a matrix, consistent with Grayson (2007), containing the zeroorder correlations and the adjusted correlations on either side of the diagonal. All correlations that were statistically significant $(p<0.05)$ before the adjustment remained significant thereafter.

These findings suggest that the relationships depicted in the model are unlikely to be inflated because of common method bias.

Following the examination of potential common method bias, the structural model was assessed. Table 3 presented below indicates that all hypothesised paths yielded statistically significant results at a 95\% confidence level. For $\mathrm{H}_{1}, \mathrm{H}_{2}$ and $\mathrm{H}_{3}$, the null hypothesis is rejected in favour of the alternate hypothesis. The model explained $71 \%\left(R^{2}=0.71\right)$ of the variance in customer satisfaction and $60 \%\left(R^{2}=0.60\right)$ in WTR. These $R^{2}$-values are considered 'large' effects according to the Cohen (1992) criteria.

The multi-group analysis procedure, suggested by Henseler et al. (2007) as extended in Henseler et al. (2009), was used to assess the differences between groups. The procedure employs a bootstrapping approach to calculate the probability of the difference between parameters in subsamples - provided the parameter estimates for subsamples are known. Furthermore, Henseler et al. (2009) state that while this approach may be considered similar to the Mann-Whitney-Wilcoxon test, an additional advantage of this approach is that it does not make distributional assumptions (Henseler et al. 2009). Table 4 reports the results of the Partial Least Squares (PLS) multi-group analysis. This table provides a breakdown of group sizes, reports the absolute difference in the path estimates $(|\beta 1-\beta 2|)$ for each group and the $p$-values $(p \leq 0.05 ;|\beta 1-\beta 2|)$ associated with observed differences in the ptath estimations.

From this analysis, it is clear that for $\mathrm{H}_{4^{\prime}} \mathrm{H}_{5}$ and $\mathrm{H}_{10}$ the null hypotheses are rejected in favour of the alternate hypothesis, suggesting that differences were noted across the defined groups. With regard to $\mathrm{H}_{4}$, it was found that the relationship between customer satisfaction and WTR was significantly different. $\mathrm{H}_{5}$ indicated that significant differences were noted between groups with regard to the relationship

TABLE 3: Path analysis results.

\begin{tabular}{llccl}
\hline Hypothesis & Path & $\boldsymbol{\beta}$ & $\boldsymbol{t}$-statistic & Conclusion \\
\hline $\mathrm{H}_{1}$ & SAT\WTR & 0.28 & $6.39 *$ & $\begin{array}{l}\text { Customer satisfaction is positively } \\
\text { associated with willingness to } \\
\text { recommend. }\end{array}$ \\
$\mathrm{H}_{2}$ & SIE\SAT & 0.84 & $78.69 *$ & $\begin{array}{l}\text { Sales interaction experience is } \\
\text { positively associated with customer } \\
\text { satisfaction. }\end{array}$ \\
$\mathrm{H}_{3}$ & SIE\WTR & 0.52 & $11.77 *$ & $\begin{array}{l}\text { Sales interaction experience is } \\
\text { positively associated with willingness } \\
\text { to recommend. }\end{array}$ \\
\hline
\end{tabular}

SAT, customer satisfaction; WTR, willingness to recommend; SIE, sales interaction experience. $*$, Significant at a $1 \%$ level. between customer satisfaction and WTR. The final significant multigroup result pertains to $\mathrm{H}_{10}$, whereby a significant difference was noted between promoters and detractors with respect to the relationship between SIE and customer satisfaction. For the remaining hypotheses $\left(\mathrm{H}_{6}, \mathrm{H}_{7}, \mathrm{H}_{8}, \mathrm{H}_{9}, \mathrm{H}_{11}\right.$ and $\left.\mathrm{H}_{12}\right)$ concerning group differences, no significant differences were noted between groups. In sum, the research appears to provide mixed results, whereby differences were noted in relationships for certain groups, but not for all groups. The nature of these results is discussed in further detail below.

\section{Discussion}

Based on the results of the path modelling, the general notion that emerging market business-to-business relationships can be strengthened if customers have positive interaction experiences with the firm has been supported. These results are consistent with various proponents of interaction experiences (Corsaro \& Cantù 2015; Biggemann \& Buttle 2009). It is suggested that a multitude of positive interaction experiences may enhance the WTR, through which the

TABLE 4: Results for PLS multi-group analysis.

\begin{tabular}{|c|c|c|c|c|}
\hline Hypothesis & $N$ & Path & ||$\beta 1-\beta 2 \mid$ & $p \leq 0.05 ;|\beta 1-\beta 2|$ \\
\hline \multirow[t]{3}{*}{$\mathrm{H}_{4}$} & \multirow{3}{*}{$\begin{array}{l}\text { Mining: } 134(13 \%) \\
\text { Construction: } \\
870(87 \%)\end{array}$} & SAT $\rightarrow$ WTR & 0.22 & $0.04 *$ \\
\hline & & $\mathrm{SIE} \rightarrow \mathrm{WTR}$ & 0.28 & 0.97 \\
\hline & & $\mathrm{SIE} \rightarrow \mathrm{SAT}$ & 0.02 & 0.23 \\
\hline \multirow[t]{3}{*}{$\mathrm{H}_{5}$} & \multirow{3}{*}{$\begin{array}{l}\text { South African: } \\
173(17 \%) \\
\text { Non-South African: } \\
831(83 \%)\end{array}$} & $\mathrm{SAT} \rightarrow \mathrm{WTR}$ & 0.28 & $0.00 *$ \\
\hline & & $\mathrm{SIE} \rightarrow \mathrm{WTR}$ & 0.25 & 0.99 \\
\hline & & $\mathrm{SIE} \rightarrow \mathrm{SAT}$ & 0.01 & 0.32 \\
\hline \multirow[t]{3}{*}{$\mathrm{H}_{6}$} & \multirow{3}{*}{$\begin{array}{l}\text { Cash: } 785(88 \%) \\
\text { Credit: } 219(22 \%)\end{array}$} & SAT $\rightarrow$ WTR & 0.13 & 0.10 \\
\hline & & $\mathrm{SIE} \rightarrow W T R$ & 0.15 & 0.92 \\
\hline & & $\mathrm{SIE} \rightarrow \mathrm{SAT}$ & 0.01 & 0.37 \\
\hline \multirow[t]{3}{*}{$\mathrm{H}_{7}$} & \multirow{3}{*}{$\begin{array}{l}\text { Focal: } 434(43 \%) \\
\text { Sales orders: } 570(57 \%)\end{array}$} & SAT $\rightarrow$ WTR & 0.02 & 0.42 \\
\hline & & $\mathrm{SIE} \rightarrow \mathrm{WTR}$ & 0.03 & 0.61 \\
\hline & & $\mathrm{SIE} \rightarrow \mathrm{SAT}$ & 0.02 & 0.21 \\
\hline \multirow[t]{3}{*}{$\mathrm{H}_{8}$} & \multirow{3}{*}{$\begin{array}{l}\text { MCC: } 815(81 \%) \\
\text { Non-MCC: } 189(19 \%)\end{array}$} & $\mathrm{SAT} \rightarrow \mathrm{WTR}$ & 0.06 & 0.71 \\
\hline & & $\mathrm{SIE} \rightarrow \mathrm{WTR}$ & 0.02 & 0.43 \\
\hline & & $\mathrm{SIE} \rightarrow \mathrm{SAT}$ & 0.01 & 0.43 \\
\hline \multirow[t]{3}{*}{$\mathrm{H}_{9}$} & \multirow{3}{*}{$\begin{array}{l}\text { EMP: } 855(85 \%) \\
\text { Non-EMP: } 149(15 \%)\end{array}$} & $\mathrm{SAT} \rightarrow \mathrm{WTR}$ & 0.04 & 0.36 \\
\hline & & $\mathrm{SIE} \rightarrow \mathrm{WTR}$ & 0.09 & 0.78 \\
\hline & & $\mathrm{SIE} \rightarrow \mathrm{SAT}$ & 0.01 & 0.43 \\
\hline \multirow[t]{3}{*}{$\mathrm{H}_{10}$} & \multirow{3}{*}{$\begin{array}{l}\text { Promoters: } 426(42 \%) \\
\text { Detractors: } 578(58 \%)\end{array}$} & SAT $\rightarrow$ WTR & 0.07 & 0.78 \\
\hline & & $\mathrm{SIE} \rightarrow \mathrm{WTR}$ & 0.05 & 0.28 \\
\hline & & $\mathrm{SIE} \rightarrow \mathrm{SAT}$ & 0.08 & $0.01 *$ \\
\hline \multirow[t]{3}{*}{$\mathrm{H}_{11}$} & \multirow{3}{*}{$\begin{array}{l}\text { NEW100: } 202(20 \%) \\
\text { Non-NEW100: } \\
802(80 \%)\end{array}$} & $\mathrm{SAT} \rightarrow \mathrm{WTR}$ & 0.02 & 0.41 \\
\hline & & $\mathrm{SIE} \rightarrow \mathrm{WTR}$ & 0.06 & 0.27 \\
\hline & & $\mathrm{SIE} \rightarrow \mathrm{SAT}$ & 0.01 & 0.39 \\
\hline \multirow[t]{3}{*}{$\mathrm{H}_{12}$} & \multirow{3}{*}{$\begin{array}{l}\text { KAM: } 533(53 \%) \\
\text { Non-KAM: } 471(47 \%)\end{array}$} & SAT $\rightarrow$ WTR & 0.09 & 0.16 \\
\hline & & $\mathrm{SIE} \rightarrow \mathrm{WTR}$ & 0.09 & 0.84 \\
\hline & & $\mathrm{SIE} \rightarrow \mathrm{SAT}$ & 0.01 & 0.71 \\
\hline
\end{tabular}

SAT, customer satisfaction; WTR, willingness to recommend; SIE, sales interaction experience KAM, key account management; MCC, (see Appendix 1); EMP, (see Appendix 1).

*, Significant at a $5 \%$ level. 
quality of business relationships can be strengthened. This relational strengthening requires a degree of loyalty, and it is, therefore, not surprising to observe that many business-tobusiness studies employ some form of loyalty measure as a dependent variable (Čater \& Čater 2009). This research has demonstrated that overall customer satisfaction is also positively associated with customers' intention to recommend. This result is consistent with the aforementioned studies in this regard.

With regard to differences in the structural model across empirically derived groups, differences were noted between mining and construction customers. Furthermore, we observed a significant difference in the link from SIE to customer satisfaction between customers that were rated as 'promoters' versus those rated as 'detractors' or 'indifferent' according to the NPS (Reichheld 2003). Net Promoter Score has received considerable research attention in customer service and relationship marketing literature (Keiningham et al. 2007a), as well as in a B2B customer experience context (Zolkiewski et al. 2017), highlighting the complexities of customer interactions and experiences. Despite marketing academics exposing several weaknesses, it remains a practical and strategic tool utilised amongst many managers. Furthermore, literature exploring the efficacy and application of NPS across markets and between customer segments remain sparse. With this in mind, it appears that the distinction between customer segments based on NPS score hold merit as promoters are seemingly more willing to recommend the firm. This intuitive understanding serves as a direct result of service interaction experiences ultimately influencing customer satisfaction.

As it is often the case in research, the non-significant or unexpected results may often yield even better insights.

In the strategy dimension, two more customer loyalty initiatives did not yield significant differences between the empirically derived groups. Firstly, no differences were observed in the path estimates for customers who are placed on the loyalty programme (NEW100) and those customers who are not invited to participate in the programme. The NEW100 programme is specifically designed to promote better customer relationships that lead to higher levels of customer loyalty to ultimately reap the associated benefits for firm performance. However, the research indicates that this differential treatment of customers does not translate into any statistically significant differences in customer WTR the focal firm. In light of this, it may well establish grounds to challenge the usefulness of the loyalty programme of the focal firm. A similar argument can be constructed for customers who are treated as key accounts. The results suggest that key account customers exhibit no differences in the path estimates compared with customers that are not considered key accounts. Again this result brings the efficacy of the KAM system, with a number of resource costs, into question.
Furthermore, no differences were observed for customers holding the MCC and equipment management project contracts. As identified, the MCC contracts are for firms that are subsidiaries of larger firms, often multinational corporations. As a result of the network advantages that these customers have and the governance requirements of their parent companies, the focal firm establishes contracts to ensure the sustainability and strategic orientation of the relationship. In theory, it is expected that because of the importance of the MCC contract, these customers will be treated with great care by the focal firm, and therefore the path estimates may differ from firms that do not have these corporate connections. However, the fact that no such differences were observed raises questions about the focal firm's ability to isolate these network enabling actors and ensure that they are managed accordingly. Similarly with the equipment management project contracts, the focal firm agrees with certain clients to perform certain equipment management functions on behalf of clients. The lack of observed differences in the path estimates between equipment management project and non-equipment management project customers may further suggest that the advantages of the equipment management project contracts do little to contribute to customer loyalty.

Finally, no differences were observed in the path estimates between cash and credit customers as well as between sales order and collection customers. Arguably, the provision of credit terms is often seen as a reciprocal investment to facilitate easier interaction and strengthen business relationships (Palmatier, Dant \& Grewal 2007).

The absence of a differential between credit and cash customers suggests that the usefulness of payment terms as a loyalty instrument should be re-examined. It would be reasonable to expect that customers that enjoy the benefits of payment terms will express their gratitude by recommending the firm. It appears, based on the results of our study, that such an assumption is seemingly ambitious.

The terms and conditions associated with business-tobusiness relationships, most notably the payment terms, loyalty programmes and contractual commitments are noted as fertile grounds for future researchers. This suggestion is offered on the basis of seemingly unexpected results in light of current literature, which suggested that a number of conditions of the business-to-business relationship would influence satisfaction, ultimately influencing one's willingness to provide recommendations.

\section{Theoretical implications}

The exploration of the association between customer experience, satisfaction and loyalty in business-to-business markets benefits from a substantial body of knowledge. The research in this area is driven by the continuous search to understand how firms seek to build stronger customer relationships in their quest for competitive advantage. 
Arguably, it would be fair to say that the literature in this area is approaching maturity and therefore our study attempted to explore an alternative view by considering the potential impact of market heterogeneity on the generalisability of a well-embedded casual chain. The causal chain itself, that is, customer experience drives satisfaction that in turn drives loyalty, is not new - especially in its simplified form as used in this study. However, researchers need to continue to test such chains across a variety of contexts in order to grasp how market heterogeneity affects the generalisation of theoretical assumptions. In addition, our model was intentionally simplified to facilitate the test across groups. Future studies may attempt such approaches with more sophisticated theoretical models on both longitudinal and cross-sectional bases.

\section{Managerial implications}

In business-to-business markets, firms need to understand the nature and circumstances of their customers because of the unique characteristics of the customers acting as organisations and buyers. Our study suggests that the assumption that the linear relationship between customer experience, customer satisfaction and loyalty holds for all market segments a firm may serve, might be flawed. Each business customer may use the service and/or products they purchase in a different fashion and therefore may derive different experiences from it. Also, the circumstances under which each business customer interacts with a supplier may be dissimilar from that of another customer or even a previous interaction episode. Thus, such heterogeneity should not surprise managers and demands their vigilant defences against complacency. Variation across customer segments may, as we have shown, cause the assumptions of how to attain customer loyalty to be limited to particular segments. Therefore, managers need to ensure that their firms acknowledge such differences and guard against generalisations that feed complacency.

\section{Limitations}

It is imperative to acknowledge the limitations that constrained the current research. A key limitation of the research is the focal firm orientation of the study that is aimed at a specific firm in a specific industry. The focal firm design does not allow for generalisation on the basis of these findings. However, one should further be cognisant of the ability of case study analyses to provide in-depth insight into the specific issues facing firms. The empirical design that was employed has a further limitation as data were collected over a specific 3-month period, and the variance in interactions during this period could not be fully accounted for. The key contribution of this study is that it not only points at potential sources of heterogeneity from an emerging market context, but also within an emerging market context, which, as a result, drives variance in causal modelling of customer loyalty relationships.

\section{Acknowledgements Competing interests}

The authors have declared that no competing interest exist.

\section{Authors' contributions}

All authors contributed equally to this work.

\section{Funding Information}

This research received no specific grant from any funding agency in the public, commercial or not-for-profit sectors.

\section{Data availability statement}

Data sharing is not applicable to this article as no new data were created or analysed in this study.

\section{Disclaimer}

The views and opinions expressed in this article are those of the authors and do not necessarily reflect the official policy or position of any affiliated agency of the authors.

\section{References}

Abratt, R. \& Kelly, P.M., 2002, 'Customer-supplier partnerships: Perceptions of a successful key account management program', Industrial Marketing Management 31(5), 467-476. https://doi.org/10.1016/S0019-8501(01)00174-2

Aksoy, L., Buoye, A., Cooil, B., Keiningham, T., De Paul, D. \& Volinsky, C., 2011, 'Can we talk?: The impact of willingness to recommend on a new-to-market service brand extension within a social network', Journal of Services Research 14(3), 355-371. https://doi.org/10.1177/1094670511404392

Anderson, J.C. \& Gerbing, D.W., 1988, 'Structural equation modelling in practice: A review and recommended two-step approach', Psychological Bulletin 103(3), 411-423. https://doi.org/10.1037/0033-2909.103.3.411

Askariazad, M. \& Babakhani, N., 2015, 'An application of European Customer Satisfaction Index (ECSI) in business to business (B2B) context', Journal of Business \& Industrial Marketing 30(1), 17-31. https://doi.org/10.1108/JBIM-07-2011-0093

Ata, U.Z. \& Toker, A., 2012, 'The effect of customer relationship management adoption in business-to-business markets', Journal of Business and Industrial Marketing 27(6), 497-507. https://doi.org/10.1108/08858621211251497

Austen, V., Herbst, U. \& Bertels, V., 2012, 'When 3+3 does not equal 5+1- new insights into the measurement of industrial customer satisfaction', Industrial Marketing Management 41(6), 973-983. https://doi.org/10.1016/j.indmarman.2011.12.002

Biggemann, S. \& Buttle, F., 2009, 'Coordinated interaction and paradox in business relationships', Journal of Business and Industrial Marketing 24(8), 549-560.

Biggemann, S. \& Fam, K., 2011, 'Business marketing in BRIC countries', Industrial Marketing Management 40(1), 5-7. https://doi.org/10.1016/j.indmarman.2010.09.004

Bloemer, J., De Ruyter, K. \& Wetzels, M., 1999, 'Linking perceived service quality and service loyalty: A multi-dimensional perspective', European Journal of Marketing 33(11/12), 1082-1106. https://doi.org/10.1108/03090569910292285

Boulaksil, Y. \& Van Wijk, A.C.C., 2018, 'A cash-constrained stochastic inventory model with consumer loans and supplier credits: The case of nanostores in emerging markets', International Journal of Production Research 56(15), 4983-5004.

Bowen, J. \& Chen, S-L., 2001, 'The relationship between customer loyalty and customer satisfaction', International Journal of Contemporary Hospitality Management 13(5), 213-217. https://doi.org/10.1108/09596110110395893

Buttle, F., 1996, 'An investigation of the willingness of UK certificated firms to recommend ISO 9000', International Journal of Quality Science 1(2), 40-50. https://doi.org/10.1108/13598539610126605

Čater, B. \& Čater, T., 2009, 'Relationship-value-based antecedents of customer satisfaction and loyalty in manufacturing', Journal of Business and Industrial Marketing. 24(8), 585-597.

Cohen, J., 1992, 'A power primer', Psychological Bulletin 112, 155-159. https://doi org/10.1037/0033-2909.112.1.155

Corsaro, D. \& Cantù, C., 2015, 'Actors' heterogeneity and the context of interaction in affecting innovation networks', Journal of Business and Industrial Marketing 30(5), 246-258. https://doi.org/10.1108/JBIM-12-2014-0249

De Haan, E., Verhoef, P.C. \& Wiesel, T., 2015, 'The predictive ability of different customer feedback metrics for retention', International Journal of Research in Marketing 32(2), 195-206. https://doi.org/10.1016/j.ijresmar.2015.02.004 
Denning, S., 2011, 'The essential metric of customer capitalism is customer outcomes', Strategy and Leadership 39(4), 12-18. https://doi.org/10.1108/10878571111 147350

Dick, A. \& Basu, K., 1994, 'Customer loyalty: Towards an integrated framework', Journal of the Academy of Marketing Science 22(2), 99-113. https://doi. org/10.1177/0092070394222001

Eisingerich, A. \& Bell, S., 2007, 'Maintaining customer relationships in high credence services', Journal of Services Marketing 21(4), 253-262. https://doi.org/10. $1108 / 08876040710758559$

Evans, K., McFarland, R., Dietz, B. \& Jaramillo, F., 2012, 'Advancing sales performance research: A focus on five underresearched topic areas', Journal of Personal Selling \& Sales Management 32(1), 89-106. https://doi.org/10.2753/PSS0885 3134320108

Ferguson, R., Paulin, M. \& Bergeron, J., 2009, 'Customer sociability and the total service experience: Antecedents of positive word-of-mouth intentions', Journal of Service Management 21(1), 25-44. https://doi.org/10.1108/09564231011025100

Fornell, C. \& Larcker, D.F., 1981, 'Evaluating structural equation models with unobservable variables and measurement error', Journal of Marketing Research 18(1): 39-50. https://doi.org/10.1177/002224378101800104

Fornell, C., Johnson, M., Anderson, E., Cha, J. \& Bryant, B., 1996, 'The American Customer Satisfaction Index: Nature, purpose, and findings', Journal of Marketing Customer Satisfaction Index: Nature, purpose,
$60(4), 7-18$. https://doi.org/10.2307/1251898

Frösén, J., Jaakkola, M., Churakova, I. \& Tikkanen, H., 2016, 'Effective forms of market orientation across the business cycle: A longitudinal analysis of business-tobusiness firms', Industrial Marketing Management 52(1), 91-99. https://doi. org/10.1016/j.indmarman.2015.05.012

Gil-Saura, I., Frasquet-Deltoro, M. \& Cervera-Taulet, A., 2009, 'The value of B2B relationships', Industrial Management and Data Systems 109(5), 593-609. https://doi.org/10.1108/02635570910957605

Gounaris, S. \& Tzempelikos, N., 2014, 'Relational key account management: Building key account management effectiveness through structural reformations and relationship management skills', Industrial Marketing Management 43(7), 1110-1123. https://doi.org/10.1016/j.indmarman.2014.06.001

Grayson, K., 2007, 'Friendship versus business in marketing relationships', Journal of Marketing 71(4), 121-139. https://doi.org/10.1509/jmkg.71.4.121

Grønholdt, L., Martensen, A., Jørgensen, S. \& Jensen, P., 2015, 'Customer experience management and business performance', International Journal of Quality and Service Sciences 7(1), 90-106.

Grönroos, C., 2017, 'Relationship readiness: Theoretical background and measurement directions', Journal of Services Marketing 3, 218-225. https://doi.org/10.1108/ directions', Journal

Gupta, S., Balmer, J. \& Low, B., 2015, 'Brands in, from and to emerging markets: The role of industrial relationships', Industrial Marketing Management 51, 4-10.

Hair, J., Hult, G.T., Ringle, C. \& Sarstedt, M., 2014, A primer on partial least squares structural equation modelling (PLS-SEM), Sage, Thousand Oaks, CA.

Hair, J., Sarstedt, M., Ringle, C. \& Mena, J., 2012, 'An assessment of the use of partial least squares structural equation modelling in marketing research', Journal of The Academy of Marketing Science 40(3), 414-433. https://doi.org/10.1007/s11747 011-0261-6

Hallowell, R., 1996, 'The relationships of customer satisfaction, customer loyalty, and profitability: An empirical study', International Journal of Service Industry Management 7(4), 27-42.

Henseler, J., Ringle, C.M. \& Sinkovics, R., 2009, 'The use of partial least squares path modelling in international marketing', New Challenges To International Marketing 20, 277-319. https://doi.org/10.1108/S1474-7979(2009)0000020014

Henseler, J., Wilson, B., Götz, O. \& Hautvast, C., 2007, 'Investigating the moderating role of fit on sports sponsoring and brand equity: A structural model', International
Journal of Sports Marketing and Sponsorship 8(4), 321-329. https://doi. Journal of Sports Marketing and
org/10.1108/IJSMS-08-04-2007-B005

Hlefana, M., Roberts-Lombard, M. \& Stiehler-Mulder, B., 2020, 'Precursors and outcome of satisfaction in business-to-business relationship building: An information communication technology industry perspective in South Africa', Acta Commercii 20(1), 11. https://doi.org/10.4102/ac.v20i1.777

Hollyoake, M., 2009, 'The four pillars: Developing a "bonded" business-to-business customer experience', Journal of Database Marketing and Customer Strategy Management 16(2), 132-158.

Hosany, S. \& Witham, M., 2009, 'Dimensions of cruisers' experiences, satisfaction, and intention to recommend', Journal of Travel Research 49(3), 1-14. https://doi. org/10.1177/0047287509346859

Humphreys, M., Williams, M. \& Goebel, D., 2008, 'Toward an enhanced definition and measurement of purchasing's strategic role in buyer-supplier relationships', Journal of Business-to-Business Marketing 15(3), 323-353. https://doi. org/10.1080/15470620802059307

Jang, J.H., Kim, S.W., Lee, Y.S. \& Kim, J., 2013, 'The effects of relationship benefit on relationship quality and store loyalty from convergence environments-NPS analysis and moderating effects', Electronic Commerce Research 13(3), 291-315. https://doi.org/10.1007/s10660-013-9117-0

Kaski, T., Niemi, J. \& Pullins, E., 2018, 'Rapport building in authentic B2B sales interaction', Industrial Marketing Management 69, 235-252. https://doi. org/10.1016/j.indmarman.2017.08.019

Keiningham, T., Cooil, B., Aksoy, L., Andreassen, T. \& Weiner, J., 2007a, 'The value of different customer satisfaction and loyalty metrics in predicting customer retention, recommendation, and share-of-wallet', Managing Service Quality: retention, recommendation, and share-of-wallet', Managing Service Quality:
An International Journal 17(4), 361-384. https://doi.org/10.1108/09604520 An Internatior
Keiningham, T., Cooil, B., Andreassen, T. \& Aksoy, L., 2007b, 'A longitudinal examination of net promoter and firm revenue growth', Journal of Marketing 71(3), 39-51. https://doi.org/10.1509/jmkg.71.3.039

Kietzmann, J. \& Canhoto, A., 2013, 'Bittersweet! Understanding and managing electronic word of mouth', Journal of Public Affairs 13(2), 146-159. https://doi. org/10.1002/pa.1470

Kim, H. \& Choi, B., 2016, 'The effects of three customer-to-customer interaction quality types on customer experience quality and citizenship behavior in mass service settings', Journal of Services Marketing 30(4), 384-397. https://doi. service settings', Journal of Servit
org/10.1108/JSM-06-2014-0194

Klaus, P. \& Maklan, S., 2013, 'Towards a better measure of customer experience', Journal of Market Research 55(2), 227-246. https://doi.org/10.2501/IJMR2013-021

Kotler, P. \& Armstrong, G., 2014, Principles of marketing. Global edition, Pearson Education Limited, Essex.

Kristensen, K. \& Eskildsen, J., 2014, 'Is the NPS a trustworthy performance measure?', TQM Journal 26(2), 202-214. https://doi.org/10.1108/TQM-03-2011-0021

Kumar, V., Sharma, A., Shah, R. \& Rajan, B., 2013, 'Establishing profitable customer loyalty for multinational companies in the emerging economies: A conceptual framework', Journal of International Marketing 21(1), 57-80. https://doi. org/10.1509/jim.12.0107

Kwiatek, P., Morgan, Z. \& Thanasi-Boçe, M., 2020, 'The role of relationship quality and loyalty programs in building customer loyalty', Journal of Business \& Industrial Marketing (in Press).

Lacey, R. \& Morgan, R., 2009, 'Customer advocacy and the impact of B2B loyalty programs', Journal of Business \& Industrial Marketing 24(1), 3-13. https://doi. org/10.1108/08858620910923658

Lance, C., Dawson, B., Birkelbach, D. \& Hoffman, B., 2010, 'Method effects, measurement error, and substantive conclusions', Organizational Research Methods 13(3), 435-455. https://doi.org/10.1177/1094428109352528

Lee, C. \& Rhee, B., 2011, 'Trade credit for supply chain coordination', European Journal of Operational Research 214(1), 136-146. https://doi.org/10.1016/j.ejor. 2011.04.004

Lemke, F., Clark, M. \& Wilson, H., 2011, 'Customer experience quality: An exploration in business and consumer contexts using repertory grid technique', Journal of The Academy of Marketing Science 39(6), 846-869. https://doi.org/10.1007/s11747010-0219-0

Lemon, K. \& Verhoef, P., 2016, 'Understanding customer experience throughout the customer journey', Journal of Marketing 80(6), 69-96.

Leonidou, C. \& Hultman, M., 2019, 'Global marketing in business-to-business contexts: Challenges, developments, and opportunities', Industrial Marketing Management 78, 102-107. https://doi.org/10.1016/j.indmarman.2018.04.016

Li, K., Fong, D. \& Xu, S., 2011, 'Managing trade-in programs based on product characteristics and customer heterogeneity in business-to-business markets', Manufacturing \& Service Operations Management 13(1), 108-123.

Lindell, M. \& Whitney, D., 2001, 'Accounting for common method variance in crosssectional research designs', Journal of Applied Psychology 86(1), 114-121. https:// doi.org/10.1037/0021-9010.86.1.114

Long Chen, H., 2012, 'Empirical behavioral analysis of project contractors' supplychain payment terms', Supply Chain Management: An International Journal 17(3) 277-289. https://doi.org/10.1108/13598541211227117

Malhotra, N., 2010, Marketing research: An applied orientation, 6th edn., Pearson/ Prentice Hall, Upper Saddle River, NJ.

Magno, F. \& Cassia, F., 2019, 'Establishing thought leadership through social media in B2B settings: Effects on customer relationship performance', Journal of Business \& Industrial Marketing 35(3), 437-446.

Murphy, W. \& Li, N., 2012, 'A multi-nation study of sales manager effectiveness with global implications', Industrial Marketing Management 41(7), 1152-1163. https:// doi.org/10.1016/j.indmarman.2012.06.012

Naumann, E., Williams, P. \& Khan, M., 2009, 'Customer satisfaction and loyalty in B2B services: Directions for future research', The Marketing Review 9(4), 319-333.

Nguyen, T., Barrett, N. \& Miller, K., 2011, 'Brand loyalty in emerging markets', Marketing Intelligence \& Planning 29(3), 222-232. https://doi.org/10.1108/ 02634501111129211

Olaru, D., Purchase, S. \& Peterson, N., 2008, 'From customer value to repurchase intentions and recommendations', Journal of Business and Industrial Marketing 23(8), 554-565. https://doi.org/10.1108/08858620810913362

Olsen, S., 2002, 'Comparative evaluation and the relationship between quality, satisfaction, and repurchase loyalty', Journal of the Academy of Marketing Science 30(3), 240-249. https://doi.org/10.1177/0092070302303005

Palmatier, R., Dant, R. \& Grewal, D., 2007, 'A comparative longitudinal analysis of theoretical perspectives of interorganizational relationship performance', Journal of Marketing 71(4), 172-194. https://doi.org/10.1509/jmkg.71.4.172

Palmer, A., 2010, 'Customer experience management: A critical review of an emerging idea', Journal of Services Marketing 24(3), 196-208. https://doi.org/10.1108/ 08876041011040604

Paparoidamis, N., Katsikeas, C. \& Chumpitaz, R., 2019, 'The role of supplier

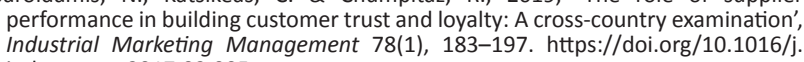
indmarman.2017.02.005 
Pardo, C., Henneberg, S., Mouzas, S. \& Naudè, P., 2006, 'Unpicking the meaning of value in key account management', European Journal of Marketing 40(11/12) 360-1374. https://doi.org/10.1108/03090560610702858

Pfohl, H. \& Gomm, M., 2009, 'Supply chain finance: Optimizing financial flows in supply chains', Logistics Research 1(3-4), 149-161. https://doi.org/10.1007/ s12159-009-0020-y

Pilehvar, A., Elmaghraby, W. \& Gopal, A., 2017, 'Market information and bidder heterogeneity in secondary market online B2B auctions', Management Science 63(5), 1493-1518.

Podsakoff, P., Mackenzie, S., Lee, J. \& Podsakoff, N., 2003, 'Common method biases in behavioral research: A critical review of the literature and recommended remedies', Journal of Applied Psychology 88(5), 879-886. https://doi.org/10.1037/ 0021-9010.88.5.879

Prayag, G., 2011, 'Paradise for who? Segmenting visitors' satisfaction with cognitive image and predicting behavioural loyalty', International Journal of Tourism Research 14(1), 1-15. https://doi.org/10.1002/jtr.837

Ramaseshan, B., Rabbanee, F. \& Hui, L., 2013, 'Effects of customer equity drivers on customer loyalty in B2B context', Journal of Business and Industrial Marketing 28(4), 335-346.

Reichheld, F., 2003, 'The one number you need to grow', Harvard Business Review $18(12), 46-54$.

Ringle, C., Wende, S. \& Becker, J-M., 2015, SmartPLS 3, Smartpls, Bönningstedt, viewed from http://www.smartpls.com.

Robb, D. \& Silver, E., 2006, 'Inventory management under date-terms supplier trade credit with stochastic demand and leadtime', Journal of the Operational Research Society 57(6), 692-702. https://doi.org/10.1057/palgrave.jors.2602042

Roberts-Lombard, M., Mpinganjira, M. \& Svensson, G., 2019, 'The antecedents and postcedents of satisfaction in business-to-business relationships in South Africa' South African Journal of Business Management 50(1), 1-11. https://doi. org/10.4102/sajbm.v50i1.212

Román, S. \& Martín, P., 2014, 'Does the hierarchical position of the buyer make a difference? The influence of perceived adaptive selling on customer satisfaction
and loyalty in a business-to-business context', Journal of Business \& Industrial and loyalty in a business-to-b
Marketing 29(5), 364-373.

Rosenbloom, B. \& Larsen, T., 2003, 'Communication in international business-tobusiness marketing channels: Does culture matter?', Industrial Marketing Management. 32(4), 309-315. https://doi.org/10.1016/S0019-8501(01)00202-4

Ryding, D., 2010, 'The impact of new technologies on customer satisfaction and business to business customer relationships: Evidence from the soft drinks industry', Journal of Retailing and Consumer Services 17(3), 224-228. https://doi. org/10.1016/j.jretconser.2010.03.008

Ryu, S., Aydin, N. \& Noh, J., 2008, 'A cross-national study of manufacturer's power structures and control mechanisms: The moderating effect of group orientation culture', Korean Economic Growth and Marketing Practice Progress 37(7) 758-766. https://doi.org/10.1016/j.indmarman.2007.09.010

Rust, R. \& Oliver, R., 1994, 'Service quality: Insights and managerial implications from the frontier', in R.T. Rust \& R.L. Oliver (eds.), Service quality: New directions in theory and practice, pp. 241-268, Sage Publications: New York.

Salomonson, N., Åberg, A. \& Allwood, J., 2012, 'Communicative skills that support value creation: A study of B2B interactions between customers and custome service representatives', Industrial Marketing Management 41(1), 145-155. https://doi.org/10.1016/j.indmarman.2011.11.021

Schloderer, M., Sarstedt, M. \& Ringle, C., 2014, 'The relevance of reputation in the non-profit sector: The moderating effect of socio-demographic characteristics', International Journal of Nonprofit and Voluntary Sector Marketing 19(2), 110-126
Schreier, M., Fuchs, C. \& Dahl, D., 2012, 'The innovation effect of user design: Exploring consumers' innovation perceptions of firms selling products designed by users', Journal of Marketing 76(5), 18-32. https://doi.org/10.1509/jm.10.0462

Seshadri, S., 2013, 'The sustainability syndicate: Shared responsibility in a transorganizational business model', Industrial Marketing Management 42(5), 765-772. https://doi.org/10.1016/j.indmarman.2013.05.014

Sheth, J. \& Sinha, M., 2015, 'B2B branding in emerging markets: A sustainability perspective', Industrial Marketing Management 51, 79-88. https://doi. org/10.1016/j.indmarman.2015.06.002

Srivastava, M. \& Kaul, D., 2014, 'Social interaction, convenience and customer satisfaction: The mediating effect of customer experience', Journal of Retailing and Consumer Services 21(6), 1028-1037. https://doi.org/10.1016/j. jretconser.2014.04.007

Storbacka, K., Strandvik, T. \& Grönroos, C., 1994, 'Managing customer relationships for profit: The dynamics of relationship quality', International Journal of Service Industry Management 5(5), 21-38.

Stocchi, L., Michaelidou, N. \& Micevski, M., 2019, 'Drivers and outcomes of branded mobile app usage intention', Journal of Product \& Brand Management 28(1), 28-49. https://doi.org/10.1108/JPBM-02-2017-1436

Uncles, M., East, R. \& Lomax, W., 2010, 'Market share is correlated with word-ofmouth volume', Australasian Marketing Journal 18(3), 145-150.

Van Tonder, E. \& Roberts-Lombard, M., 2016, 'Customer loyalty guidelines for independent financial advisers in South Africa', Acta Commercii 16(1), 1-10. https://doi.org/10.4102/ac.v16i1.337

Venkatesh, V. \& Bala, H., 2008, 'Technology acceptance model 3 and a research agenda on interventions', Decision Sciences 39(2), 273-315. https://doi. org/10.1111/j.1540-5915.2008.00192.x

Venkatesh, V., Davis, F.D. \& Morris, M.G., 2007, 'Dead or alive? The development, trajectory and future of technology adoption research', Journal of the Association for Information Systems 8(4), 1. https://doi.org/10.17705/1jais.00120

Verhoef, P., Lemon, K., Parasuraman, A., Roggeveen, A., Tsiros, M. \& Schlesinger, L., 2009, 'Customer experience creation: Determinants, dynamics and management strategies', Journal of Retailing 85(1), 31-41.

Völckner, F., Sattler, H., Hennig-Thurau, T. \& Ringle, C., 2010, 'The role of parent brand quality for service brand extension success', Journal of Service Research 13(4), 359-361. https://doi.org/10.1177/1094670510370054

Walter, A., 1999, 'Relationship promoters: Driving forces for successful customer relationships', Industrial Marketing Management 28(5), 537-551. https://doi. org/10.1016/S0019-8501(99)00081-4

Williams, P. \& Naumann, E., 2011, 'Customer satisfaction and business performance: A firm-level analysis', Journal of Services Marketing 25(1), 20-32. https://doi. org/10.1108/08876041111107032

Witell, L., Kowalkowski, C., Perks, H., Raddats, C., Schwabe, M., Benedettini, O. et al., 2019, 'Characterizing customer experience management in business markets', Journal of Business Research 116(1), 420-430.

Yurynets, O. \& Tomiuk, O., 2014, 'Justification of multilevel marketing strategy structure of automotive enterprises', Economic Annals-XXI 1-2(2), 48-51.

Zablah, A., Bellenger, D. \& Johnston, W., 2004, 'An evaluation of divergent perspectives on customer relationship management: Towards a common understanding of an emerging phenomenon', Industrial Marketing Management 33(6), 475-489. https://doi.org/10.1016/j.indmarman.2004.01.006

Zolkiewski, J., Story, V., Burton, J., Chan, P., Gomes, A., Hunter-Jones, P. et al., 2017 'Strategic B2B customer experience management: The importance of outcomesbased measures', Journal of Services Marketing 31(2), 172-184. https://doi. org/10.1108/JSM-10-2016-0350 


\section{Appendix 1}

TABLE 1-A1: Customer segments for multi-group analysis.

\begin{tabular}{|c|c|c|}
\hline Theoretical dimension & Group name $\dagger$ & Description \\
\hline \multirow[t]{2}{*}{ Market characteristics } & NEWDUS & $\begin{array}{l}\text { More than } 95 \% \text { of the customers of } \\
\text { the focal firm are in mining or } \\
\text { construction. Therefore, mining } \\
\text { customers were compared with } \\
\text { construction customers. }\end{array}$ \\
\hline & NEWSA & $\begin{array}{l}\text { The focal firm conducts its business } \\
\text { across multiple country markets. This } \\
\text { study included responses from more } \\
\text { than clients in the following multiple } \\
\text { African countries. }\end{array}$ \\
\hline Interaction characteristics & NEWCASH & $\begin{array}{l}\text { The focal firm distinguishes between } \\
\text { customers who pay cash for parts } \\
\text { versus customers that use credit. }\end{array}$ \\
\hline
\end{tabular}

Motivation

There may be differences in the types of products and/or services that mining customers purchase - as compared with construction customers.

Conventional International marketing literature suggest that customer loyalty experiences can vary across cultural contexts (Murphy \& Li 2012;

Rosenbloom \& Larsen 2003; Ryu et al. 2008)

The advantages and disadvantages of cash payments and providing custome credit are well documented in management literature. Although cash payments may hold specific benefits for the cash flow and ultimate financial performance of the firm, providing performancedit can reap pubstang relational benefits.

NEWBILL The focal firm distinguishes between customers who prefer to use sales orders, versus customers that collect their parts from the focal firm.

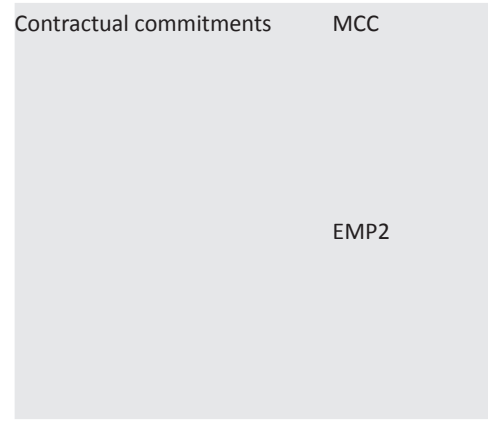

Strategy initiative

LOYCAT2

Many of the focal firm's customers are subsidiaries of larger firms. For some of these, the focal firm typically establishes a management contract with the holding firm to ensure that the relationship is also manare that higher level.

This is another initiative to promote customer relationships, is that the focal is that the foca firm established so-called equipment management contracts with some
customers. Under this project, the focal firm is contracted to maintain and manage equipr
customers.

The focal firm uses conventional methods to calculate Net Promoter methods to calculate Net Promoter Score (NPS) for all its customers. The firm is then able to separate 'promoter customers from 'detractor' customers. In the focal firm this programme independently from the loyalty
programme depicted in NEW100.

NEW100

The focal firm has a programme which allegedly differentiates between the allegedly differentiates between the best performing customers based on
purchasing volumes and the rest of the curchamer base. Note that it is not customer base. Note that
limited to 100 customers.

NEWKAM In addition to various loyalty programs the focal firm also establish Key the focal firm also establish Key Account Management (KAM)
arrangements with certain clients.
Billing type represents an interaction variation, and it is therefore useful to establish if differences exist between sales order customers and collection customers.

Consistent with Williams and Naumann (2011) and Yurynets and Tomiuk (2014), it is reasonable to expect that for the customers with parent firm contracts manament, the focal firm will make cill make are well managed.

Participation in this project suggests that the focal firm extends its services and thereby creates a seemingly deeper form of collaboration with certain customers. scholarly attention (Jang et al. 2013; Kristensen \& Eskildsen 2014) and its usefulness is rigorously debated in the B2B literature and beyond. It is B2B literature and beyond. It is
conceivable that the experiences of conceivable that the experiences of
promoters are different from detractors.

If the loyalty programme meets its objectives, it can be expected that customers who are invited to the loyalty customers who are invited to the programme exhibit significant
differences (higher) to those who are differences (higher) to th

If the KAM initiative of the focal firm is effective it can be expected that effective it can be expected that treatment will respond different to treatment will respond different to
The Net Promoter Score has received
Hypothesis

$\mathrm{H}_{4}$ : There are significant differences between the path estimates for mining versus construction customers.

$\mathrm{H}_{5}$ : There are significant differences between the path estimates for 'South African' versus 'non-South African' customers.

$\mathrm{H}_{6}$ : There are significant differences between the path estimates for cash customers versus credit customers.

$\mathrm{H}_{7}$ : There are significant differences between the path estimates for customers who have customers collect their purchases from the focal firm, versus custom the use sales orders.

$\mathrm{H}_{\mathrm{s}}$ : There are significant differences between the path estimates for 'MCC customers' versus 'non-MCC customers'.

$\mathrm{H}_{9}$ : There are significant differences between the path estimates for 'equipment management project customers' versus 'non-equipment management project customers'.

$H_{1}$ : There are significant differences between the path estimates fo 'promoter customers' versus 'detractor customers'.

$\mathrm{H}_{11}$ : There are significant differences between the path estimates for NEW 100 customers versus non-NEW100 customers

$\mathrm{H}_{11}$ : There are significant differences between the path estimates for 'KAM customers' versus ' non KAM' customers

\footnotetext{
$\dagger$, A fictitious name assigned to the programme to protect the identity of the focal firm and facilitate the analytical procedures.
} 